\title{
The Potter's Field
}

\author{
GRAHAM DENYER WILLIS
}

University of Cambridge

\section{INTRODUCTION}

The "potter's field" - indigent cemetery, pauper's burial ground, pit grave-is a category and practice that has existed for centuries. Today the term is bandied about loosely, affixed both to spatial locations and to kinds of bodies in space. The idea is this: the potter's field is where the most worthless are buried, usually in "communal" conditions. It is a location where the everyday techniques of governance, and their byproducts, are concentrated and made material.

Take the case of New York City. Here, an entire island-Hart Island-is a potter's field. It is abstracted from public view. Yet the bodies buried there have been actively predated and "cared for" in a range of ways. Insurance firms, old age homes, hospitals, and the prison system shape these subjects of a condition in which the inability to pay to be laid to rest defines the result. At Hart Island, these bodies are buried in mass graves dug by industrial machinery and filled in by prison labor paid 50 cents an hour, often after "benefitting science" at elite New York City Medical Schools (Bernstein 2016). The bodies of the potter's field, like those who bury them, are deeply marked by race, evidenced as much in the lives left to die as in their ultimate condition of material disposal. Historically, this is especially acute: the potter's field has been where victims of lynching, hanging, and racialized violence have been put in their place.

Acknowledgments: This article has benefited from much intellectual heavy lifting that is not mine. I am deeply indebted, first, to the CSSH editors and reviewers, who participated fully in making this work better. Their investment epitomized the critical and substantive collegiality that makes scholarly work unique. I am grateful to several colleagues who graciously and constructively engaged with this article in its multiple forms and helped turn it from a series of premises and inflection points into something more coherent. Finn Stepputat, Jeff Garmany, Ieva Jusionyte, Laurie Denyer Willis, Anthony Fontes, Kevin Lewis O’Neill, Kristen Drybread, and Winifred Tate all took the time to reflect on partial or entire drafts. Some ideas were further enriched in conversations with Sharika Thiranagama, Samira Bueno, and Thomas Blom Hansen. Special thanks go to Amy Jaffa and Max Horder, two rising scholars who will soon make significant waves. Thanks also go to participants in the Political Sociology Reading Group at the University of Cambridge and to attendees at a Stanford Department of Anthropology presentation. All translations are my own. 
Furthermore, the potter's field has been decisively shaped by governing logics as they shift over time.

And yet, in some places potter's fields are also spaces where disinterment is standard and where political massacres of past and present blend together in human fragments. Especially in Latin America, direct and indirect violence leads straight to churning urban cemeteries that are endlessly sowed, unsowed, and re-sowed again (O'Neill 2012; Klaufus 2016; Fontes n.d.). A case in point is the potter's fields in the city of São Paulo, Brazil, where little is sacrosanct or made invisible. Dogs traipse, shitting, pissing, and digging where they please. Bits of coffin are everywhere. Scraps of button-up shirts lie partially buried all around. Do not take your eye off the ground or you will fall in. This terrain is a mundane mass grave; a space of disposal en masse.

This article is motivated by what I see as the more or less accepted blending, tactile or imperceptible, of devalued life and earth inside and outside of certified cemeteries in contemporary times. To contain the dead bodies produced by liberalism is too burdensome. They blow across bureaucratic boundaries and spatial containments. Moreover, the byproducts of the violence of abandonment and the violence of policing, and what they enable, need not be circumscribed by the state in cemeteries or geomorphic Hart Islands. Others now do the burying of the "worthless" and the criminal elsewhere, expanding the dimension of the potter's field beyond legal certification.

In what follows, I unpack the "potter's field" as an everyday practice and category as it evolves in the material treatment of dead bodies and body parts. "Social death" is not just a category of the living; there is a concordant material, subterranean, but fluid space of the dead. From São Paulo, I show how in the past, as now, the potter's field has been politically useful for hiding bodies, but in different ways over time. In the Cold War, the potter's field was where Brazil's national security state hid assassinated and tortured political insurgents. Today, it is where the violence of abandonment and the violence of policing are made mundane, and responsibility is interred. Those buried here are deemed disposable, and responsible for their condition in both life and death.

Abandonment, today, generates uncertified cemeteries. Around this city there are tens, perhaps hundreds, of de facto cemeteries where the "worthless" and "criminal" are disposed of without political rupture. Uncertified cemeteries are a material condition inseparable from governance by abandonment. They may not be "legal" spaces, but they are pedestrian, and de facto authorized, in keeping with the selectivity and absent presence of the state that has become commonplace around the world (Goldstein 2016). These cemeteries are all around, reflecting emergent but sustained patterns of governance by alternate orders, the outcome of a politics that uses landscape as a weapon (De León 2015), and the ways in which others like hospitals, "experiment" with abandoned and devalued life. Though states govern the dead (Stepputat 2014), I propose that the potter's field, as governance itself, has moved 
beyond state bureaucracy. It does not much matter that uncertified cemeteries are made by others, so long as they do not contain the wrong kind of people. It becomes news when they do.

These uncertified potter's fields are revelatory in showing that dead bodies seem to fertilize and give life to particular kinds of death-circling sociality. These sorts of sociality are an especially tricky kind of material and social "potentiality" (Simone 2016), especially distinctive, it seems, in the current moment. To illustrate, I point to the terrestrial and material artefacts of what "organized crime," as a social infrastructure, leaves in the earth. In cities throughout Latin America uncertified cemeteries now banally dot urban spaces. Potter's fields, whether tended by the state, organized crime, or others like hospitals, are the infrastructural dirt of contemporary politics, vital for understanding emergent political change and its foreclosure.

I unfold my discussion in five parts. I first provide some background on how I arrived at this analytic space and how I propose to try to make sense of it. I then consider how scholars have approached the potter's field historically and more recently, often with an eye to the communities on the edge of falling in. In my third section, I look more empirically to Latin America and shifting patterns of governance and violence there, and their correlated patterns of graves. I follow this with an assessment of how these spaces are used for political purposes, such as for hiding "valuable" bodies or making direct violence disappear quietly. Finally, I discuss the potter's field as it exists in uncertified and de facto ways via its terrestrial coordinates in São Paulo. I conclude with some thoughts about why such cemeteries demand scholarly and political attention and how potter's fields today are as revealing and meaningful as ever.

MATERIAL MOTIVATIONS

From 2009 to 2012, I carried out ethnographic research with homicide and other detectives of the Civil Police in São Paulo (Denyer Willis 2014; 2015; 2016; 2017). I accompanied them as they investigated homicides that are so routine in this city, as well as the nearly as routine police shootings of citizens, known then as resisting arrests followed by death. It was here that the cemetery began to coalesce for me as a specter of governance. Revisiting my field notes, I recall one case that happened, peculiarly, on the Day of the Dead:

Dia dos Finados - The wind sways the eucalyptus trees overhead. There is a hushing sound. We are no longer in the city, as expansive and endless as the city of São Paulo is. The two-lane road is blocked, and a Military Police officer directs traffic as it comes, from both sides, when it comes. We are mulling at the scene of a police shooting. The homicide detectives I am accompanying have been sent out to this place, on the outskirts of the city. Here a young man shot and was shot. He was in his early twenties. The Military Police car in pursuit came to rest abutting a curb, diagonally on the street. Facing it is a motorcycle askew on the ground. He had a military-grade assault rifle, the police told us. The police car's hood has been furado - "punctured" with bulletsthe metal literally peeled back in some places. These were bullets that "belong" on 
the fields of war. The police involved in the shooting speak with a visible sense of relief. It was not their skin or their bones peeled back. The young man is now lying in a zippered grey bag in the morgue in town. We go there next. But the detectives already know he is like most of the 832 others killed by police in 2015 in this city. ${ }^{1}$ Down the street, not more than 500 meters away, is a cemetery. Modest families mull and pass around the brick and mortar walls that surround it. There are flowers. Many flowers, arranged ornamentally, thoughtfully. Many are plastic.

During this research I observed how everyday practices of claiming and defending certain lives for legal protection are reinforced or overturned. While with these detectives, I waded through the mire of the Brazilian state's selective and minimal engagement with many lives. On occasion we visited "fields" where bodies had been either purposely buried or had simply been left, undetected and unclaimed, to blend and disappear. Detectives were routinely confronted with something I thought was audacious: there are cemeteries in the city used routinely by people not authorized to do so by law. For example, in 2012, a university in an historic São Paulo neighborhood was decertified, leaving its 2,100 registered students in the lurch. Three months later, something else uncertified was unearthed in the university's yard. Acting on a tip, the homicide detectives I was with discovered fifteen bodies in a cemitério clandestino. The jumbled remains of these bodies-young, old, fetuses, and parts of bodies - had been tossed asunder in a shallow communal grave. The rector of the former university released a statement affirming that the bodies had been part of a study by the school's medical arm - they had benefitted science. Since the school had been deactivated years before, she had ordered the bodies be disposed and they were interred in a courtyard. There was no explanation of where they had come from. The response of pragmatic and resource-poor detectives to these kinds of cemeteries was often a shrug. It was just more death.

During this period of my research I never entered a certified cemetery. They stood in the background, brick and mortar reifications that appeared stable and static. But as I concluded my research, forty-three students in Ayotzinapa, Mexico were "disappeared" following a protest. In the search for them investigators carried out a forensic investigation of a suspected mass grave on the city's outskirts, where a witness claimed the bodies had been burned and disposed of. During the excavation the analysts found charred fragments of other bodies. The site was a cemetery that was not a cemetery. But it did not seem to matter who those others were. They were material but unexceptional evidence of how violence is historically layered in ways that are difficult to disentangle.

\footnotetext{
1 The data is from São Paulo state statistics. They include on- and off-duty shootings by police from the two main police institutions: Polícia Civil and Polícia Militar (the Civil Police and the Military Police).
} 
I looked further into the situation in São Paulo and the finalities of bodies in and out of cemeteries there, as "made" by violent policing and under the violence of political abandonment. In 2016, I began to study two city cemeteries, Dom Bosco and Vila Formosa, both of which had spaces for pauper's burials. One afternoon, I stood beside a row of open graves in a part of Vila Formosa that was for the urban poor, where each arriving casket was allotted 15 minutes for burial. These were not nameless paupers; they came with families, social ties, and wailing, and yet the treatment of these bodies was hardly different from those buried nameless.

In one open grave, next to another that was being filled by pallbearers and family, was a bone (see figure 1). Looking as though it had been placed there intentionally, it had been left behind during routine disinterment that morning. Gravediggers and others walked around the edge of the grave as they placed a casket in an adjacent one. Some of them looked in, noticed the bone, and moved on. No one mentioned it or pointed it out. It was a worn old femur, the largest human bone. It was evidence of nothing, and apropos of nothing but a proliferation of bones. Ten minutes later a new casket was placed on top of it.

I was left to wonder what really counts as the beginning and the end of the potter's field when all bodies of the urban poor are buried in graves where bones are jumbled, left behind, and treated like soil. Dom Bosco and Vila Formosa are the two places where the "formally unclaimed" are sent for burial in certified potter's fields. But they are also where the urban poor who receive free burials go. This slippery lack of distinction in how the bones of the unclaimed and the poor are treated, in these cemeteries and elsewhere, motivates the enquiry that follows.

\section{PUTTING THEM IN, KEEPING THEM OUT}

The potter's field has been overlooked in scholarship, although study of it overlaps in narrow ways with vital work on Cold War and historic mass graves (Rosenblatt 2015; Rubin 2015), the political lives of dead bodies (Verdery 2013), and the socio-cultural meaning of death (Riley 1983; Baudrillard 1993; Kaufman and Morgan 2005; Lomnitz 2005). But I see particular urgency in considering its significance today, since the potter's field has proven remarkably durable and universal in this moment of liberal globalization and individual responsibility.

In The Work of the Dead, Laqueur (2015) argues for recognition of the "age of the cemetery," in which a decline in churchyard burials and the expansion of private funereal interment took place, following on larger structural changes that occurred in patterns of political order and industrialization. Privately run cemeteries became deeply intertwined with Victorian urbanization and new foundations of capitalist production, emerging as commoditized terrains. In this period of emergent division and reordering, these were classed 


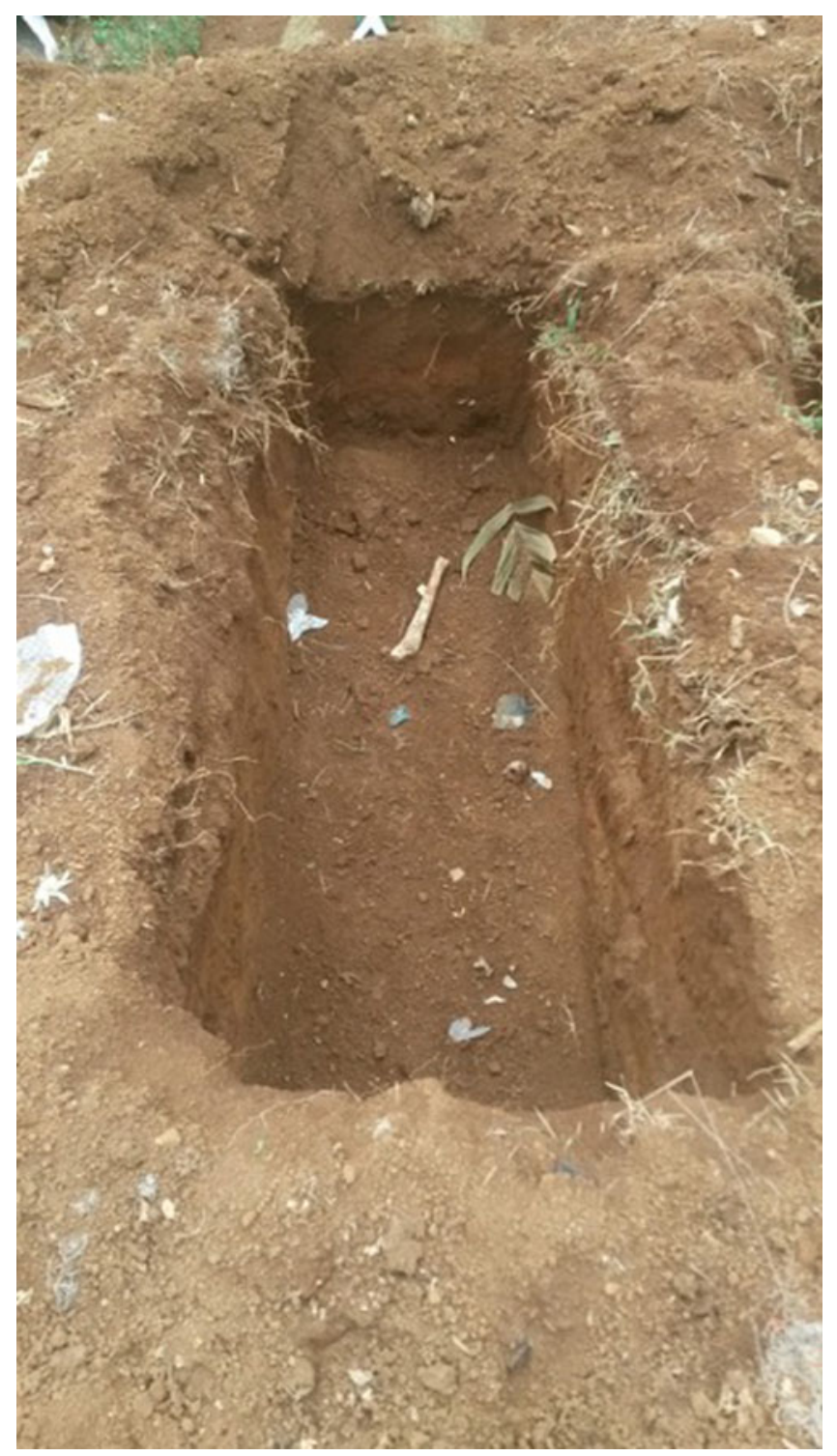

FIGURE 1. Femur.

spaces that central government legitimized but did not necessarily administer. They were driven by a particular specter of that which they were not: a mass grave. Under this new logic of class, spatially demarcated in earth, abandonment in death became a severe truth for the living. The imaginary of the 
undignified pauper's funeral that no one attended or commemorated drove sales of individual private cemetery plots (ibid.). The image of being interred in a pit in a jumbled and festering mess with nameless others was a powerful motivation to find an alternative.

Analytically, the fragments of this literature reveal two things about the conditions of death. First, the classed cemetery was inseparable from a rapidly expanding urban condition. Intensifying conditions of abandonment, and their spatial manifestations, needed to come to rest in mortality somewhere. Never directly addressed in the descriptive work of early urban scholars like Engels (1892), the mass grave, or French fosse commune, is hardly obscured behind dramatic descriptions of the early urban and industrial condition, including abject mortality, desertion of children, and the unhindered obliteration of readily disposable labor. If the early urban condition was about expendable labor, in factories and distant colonial plantations, it was also about controlling criminality. The transience of the urbanizing city, the newness of its inequality and abjection, its densification, and the rise of new kinds of criminal disorderwhich would drive the creation of police as we recognize them today (Rawlings 1995) — were well encapsulated in an ominous and well-avoided urban symbol, the "one horse hearse with a pauper-load" (Laqueur 2015: 318). No citizen wanted to be that cargo.

The second thing revealed is that the specter of the urban potter's field inspired new forms of social and economic organization designed to keep people from falling into it. Focusing on a population on the edge of the potter's field in urbanizing America, DiGirolamo (2002) considers how street level "newsboys" in the late nineteenth century struggled to not be buried nameless in a pile of bodies. Newsboys were largely poor and sometimes orphans, and they often formed trade groups. What makes this population remarkable, DiGirolamo argues, is that the threat of the potter's field inspired solidarity. Newsboys took up collections and created poor but "pitifully elaborate" funerals to avoid dehumanized, indigent mass burials (ibid.: 5).

In England around this same time, the specter of the mass grave was similarly powerful in engendering new kinds of institutions. The rise of for-profit cemeteries spurred the development of "burial societies." These were systematic but basic forms of insurance to cover costs of death, sickness, and funerals. Laqueur elaborates: "By 1874, two and a quarter million people, mostly men, belonged to friendly societies which provided death and sickness benefits; to this figure must be added their spouses who were insured for funeral only" (1983: 110).

In Victorian England the mass grave became something of a pseudonym for subsequent practices. It represented the possibility of a body being pulled apart after death. The 1832 Anatomy Act in England allowed for pauper bodies to be dissected for medical investigation before their final burial in a mass grave. This new law made an implied practice normal. Previously, this 
treatment had been reserved for hanged felons or racialized "criminals," but under new certification the trade in pauper bodies redrew the normative categories of the living, with science as justification. Hurren (2004) shows how this political effort to create medical knowledge was deeply entangled with early Victorian Poor Laws and expanded government anti-welfare policies, both of which facilitated the provision of bodies. One clear beneficiary was the Cambridge Anatomical School at the university's Downing College. Cambridge received bodies from around the region, leveraging the political moment of disposable bodies to advance its dominant position in health science research. The same pattern of pauper body trafficking was crucial to the creation of medical knowledge in the United States (Blakely and Harrington 1997; Sappol 2002).

The potter's field and its uses are maintained, even as they change in direct relation to the governing logics of life. The later New Poor Laws (1880-1914), which advanced the penal philosophy of the workhouse and emergent notions of care, expanded the use of the mass pauper grave. Here, the pit grave was governed through the idea of work; poverty - the "absence" of work - came to replace abandonment and missing kin or social ties as a defining logic for determining who would end up there. Strange (2003) argues that a pauper's burial in this late Victorian period was especially abhorrent because it denied rites and mourning customs even when the dead did have family. Burial "on the parish" meant not anonymity (necessarily), but rather strict central government control over the impossibility of commemoration — only a plain pine box was allowed, with no individual markings or space for mourning. This "ultimate disgrace" (Thompson cited in ibid.) sometimes inspired people to try to get their kin out of the pit, even years after their burial. Some families applied to exhume bodies from communal graves once they had found the money to pay for a proper burial (Strange 2003). Such was the logic of the workfare New Poor Laws, and the evisceration of poor lives in death was a powerful governing technique for driving economically productive life.

Studies of pauper's mass graves and the potter's field have spoken predominantly in the past tense. Surprisingly little work has dealt directly with these spaces as a material or governance condition. What contemporary research does exist follows a similar thread, examining how people remain terrified of falling into the space or of letting certain others fall in. Writing of a public hospital in Australia, Fox (2005) describes how social workers there are, structurally, the last resort for defining who gets a funeral and who is buried in an unmarked grave. Similarly, Castex (2007) considers the ways that the last line of service in social work itself is to cobble together enough resources to prevent clients being buried by numbered stake only. In the United States, this means running between embassies, places like the Bureau of Indian Affairs, or fundraising with cap in hand to accesses legal means of identification (DNA, photographs, fingerprints). In other words, such 
workers routinely scrape together whatever resources they can to keep people out of the pit.

There has been recent and important comparative work. Kim (2016) studies the homeless or near-homeless in Japan, a population defined largely by weakened or severed ties with family and kin. Here, the fear of kotodushi, "isolated death," is powerful, and it drives a kind of "necrosociality"-mutual commemoration and care for the condition of the dead and the materials of their memory. Kim describes how a welfare shelter came to create a communal tomb for the dead where the remains of day laborers, the mentally ill, and other muen - those "without ties" - of the organized underclass are placed to rest.

This same line of "organization on the edge" is echoed in the few contributions on the subject from Latin America. Kristen Drybread's (2013) incisive work on street children in the Brazilian northeast considers the specter of ignominious disposal for these small "indigents." These street children anticipate an early death, and what matters for them is to be surrounded and commemorated in death rather than being left to the vultures on a trash heap. Drybread recalls a conversation among them in which one boy tells how the state treated a peer after he was killed by an extermination squad: "No one claimed the body, so the folks at the morgue stuffed him in a plastic bag and threw him in the pit" (ibid.: 217). Similarly, the mass grave emerges ever so slightly in the work of Jones, Herrera, and de Benítez (2007) about street children and suicide in Puebla, Mexico. While groups of children organize to provide a casket, they are nonetheless confronted by logics of Catholic judgment and burial for the "sin" of killing oneself, which means burial face down in a common grave.

MASS GRAVES: FROM EXCEPTIONAL TO MUNDANE TERROR

Today the study of mass graves references history, often pointing decisively to the Cold War, which was infamous for a particular kind of violence (Gordillo 2002; de Walque 2005; Heryanto 2006). This is especially true for Latin America, where during the second half of the twentieth century millions were killed, tortured, and disappeared. Militaries and police pursued dramatic counterinsurgency campaigns, often as newly centralized forces (Gill 2004; McSherry 2012). Paramilitary groups at wrist's length from the state, like extermination squads and "communist hunters," ran roughshod in city and countryside massacring real or perceived political insurgents, indigenous communities, and even academics (Koonings and Kruijt 1999; Sluka 2000). On the other side, leftist rebel groups and urban guerillas strove to destabilize authoritarian regimes by perpetrating their own bloody massacres, kidnappings, and strategic bombings (Rochlin 2003).

The result was many bodies in need of burial. The earth of the region received this violence in marked and unmarked graves and in clandestine and public sites of mass burial. In Guatemala, massacres of indigenous populations became almost routine, as did the sites of bodily disposal. Wilson speaks 
of stumbling upon a "clandestine" grave that everyone in the village knew about, where years after the violence, "The bodies laid where they had been tossed, untouched and unrecovered" (2001: vii). More commonly, the perpetrators of this violence sought to obscure the finality of those they had killed, not necessarily due to a fear of being held to account, but rather because the political dead deserved anonymity, namelessness, or existence alongside unremarkable and dead indigents. The corpses of the disappeared and killed were subjected to a "deliberate commingling of remains in unmarked graves" (Ferrándiz and Robben 2015: 1). They became symbolically nameless "political indigents," now incapable of inflaming political will and insurgency among the living. Mass graves and disappearances were about stripping away political resistance en masse, both through multifarious murders and via the terrifying silences of those never heard from again.

The Cold War is over now and the hegemonic liberal project asserts that violence has subsided. Efforts to reclaim the silences of the "missed people" are now center stage in new struggles for democratic voice and the construction of liberal capitalism as a project. Such violence is treated as a historical project. Muddy and painstaking searches are ongoing in many countries today, emphasizing, materially, the way that a body — its bones - may bring some resolution to a specific period of victimhood and wrongdoing. This wrongdoing can be literally and figuratively unearthed from the mass grave, definitively and scientifically asserted, propelling a political discussion of liberal justice. The release of historical documents, sometimes slowly, sometimes in unexpected troves, has pushed forward efforts in the same vein (Weld 2014). Exhumations of political dissidents, and the broader reconciliation projects concerned with the moral crises of the past, have become central to many scholarly discussions about righting the wrongs of "then" (Rosenblatt 2015; Wilson 2001; Sanford 2003). But the mass graves of this current interest are typically seen in the light of systemic or normative ruptures, of genocides, civil wars, dictatorships, or analogous catastrophes.

Liberal hegemony minimizes the need to commingle valuable and un-valuable bodies in earth. Violence is now subsumed in the dualism of direct violence and the violence of abandonment, and what abandonment enables (Scheper-Hughes 1993; Bourgois 2001; Biehl 2005). Those who are buried nameless, unmarked, and uncelebrated are so, still, by political definition, and under hegemony, in ways that remain largely uncontested. Today, the ongoing police violence in liberal democracies, or the ways in which real or perceived criminal populations are left to kill each other, have meant that bodies can pile up, more or less unhidden, yet be maintained as invisible and unexceptional by a paradigm of suitable victimhood (Nagengast 1994; Samet 2013). The lived experience of democracy - twenty-plus years after countries emerged from the terror of authoritarian governments - maintains a particular delineation of which lives matter. 
Massacres still take place. There is a vast discussion of the ways that the violence of today is contiguous and mixed with that of the dictatorship past, and is in some cases increasing (Mitchell and Wood 1999; Cingranelli and Richards 1999; Aretxaga 2003; Comaroff and Comaroff 2006). Terror continues to define and prop up the political present, sustaining it with deep contradictions (Arias and Goldstein 2010). But this historical moment of state terror has been made invisible and left unrecognized, confined largely to populations that democracy-as-project continually fails to "emancipate" or is disinterested in emancipating.

State terror is now twofold: It is direct violence that many condone by recognition or omission, or minimally acknowledge via pseudonyms or socially acceptable metaphors such as the War on Drugs, stop and frisk, or hyperincarceration. It is also the space of abandonment, and a practice of abandonment as a form of rule, in which direct violence is made possible, logical, and uncontestable (Taussig 1984). Under these conditions, to be terrified is to recognize the impossibility of predicting violence, the likelihood of it happening, and the slipperiness of resistance to it. Terror has become a question of position and implied power: intense and horrifying for some, invisible and unimportant for others. To systematically resist the hegemonic practice of violence is to open oneself to not just the possibility of violence, but its certainty.

In the divided cities of contemporary Latin America this terror is extreme. Consider Alves' observation that the practices of routine police violence in São Paulo are bleak and uncontestable. Alves recounts a story told to him by a mother, Dona Lurdinha, whose son's neck police snapped as she wailed for them to stop: "I knew they had broken it," she said, "because I saw he was trying to grab the gate and his hands stopped in the air ... right here, in front of me" (2014: 146). The police did not feign justification and she would have no resolution or recompense.

Her experience is unexceptional, and few police are ever held responsible for such violence. To the contrary, they have little to fear, even if they dramatize violence. In 2016, police in São Paulo circulated a series of photos in a WhatsApp group that showed an officer holding an axe to the head of a young black man. With a Military Police vehicle visible in the background, the officer wears a clown mask from a horror film, points a gun at the man's forehead with one hand, and rests the axe on his head with the other. The young man clasps his hands together, bending over in obvious fear.

But these actions and massacres on behalf of political power, which sustain the ability to deny the existence of state terror, are not just mundane occurrences with one or two victims. Massacres of four, five, or six people are routine. In May of 2012, while I was undertaking research in the homicide division of São Paulo, members of one notorious police group, ROTA, executed six young men in what was described in the police report as a "gunfight." The incident was in fact a massacre and an execution, as related to homicide 
detectives by a witness who saw police remove one of the men from their car beside a major highway miles from the scene and shoot him. Despite police claims of a firefight, no police were injured, nor did their cars sustain any damage. Three officers were arrested, but after two years of trials and a substantial burden of incriminating evidence, they were declared innocent and returned to duty.

Central to this story is that the six people killed were alleged to be members of São Paulo's organized crime group, the Primeiro Comando da Capital (PCC). When it is not police doing the killing, violence between those who are deemed less valuable is nonetheless legitimated under an implied logic of "let them kill each other." This sort of violence is part of a larger pattern found in spaces of this and other cities that outsiders seldom see, where shadowy para-state groups carry out multiple killings, known as chacinas, with remarkable regularity.

Not surprisingly, the young men suspected of gang and organized crime violence are routinely cast as liberal pariahs, antithetical to the civilizing project and uncivil in their "barbarity" (Holston 2009: 25). The "they" is, of course, a broad category, which draws on racial, gendered, and spatial tropes that make it easy to dismiss the victims and perpetrators as unimportant and their lost lives as inconsequential due to their distance from categories of "innocence" and "civility." To put this differently, whether Dona Lurdinha's son or the young man with an axe to his head were or were not involved in crime is irrelevant. The political space they inhabit - one freely predated by police and the violence of abandonment - traces how bodies are placed in earth. These conditions underpin, and fill, the potter's field today as it has come to transcend state-certified spaces.

\section{OMMIN G L IN GS}

In discussions of violence and democracy in Latin America scholars often reference Brazil's 1992 Carandiru prison massacre (Mitchell and Wood 1999; Ahnen 2003; Wacquant 2003). In this single incident riot police used machine guns, shotguns, knives, and bombs to kill 111 inmates. This case has been theorized and historically situated as it relates to institutions, citizenship, and the development and emergence of organized crime in the post-Cold War period (Caldeira 2000; Darke 2013; King and Valensia 2014; Silvestre 2016). But this massacre is simply one instance in an historical arc of violence against marginal populations, especially as those populations amalgamate class and racial categorizations. Where the bodies of those killed at Carandiru ended up hints at the historical congruence of the potter's field.

They came to Vila Formosa, Latin America's largest cemetery. This is a vast and deeply unsettling place. Empty holes of red earth yawn everywhere. Remnants of past graves - broken portraits, granite plaques, pieces of clothing-scatter the fields, making it difficult to know what or who is under 
what spot. The grounds are expansive- 780,000 square meters. In colloquial discussions, many have told me that the only larger cemetery is in China. Yet the right metric for measuring size may not be square meters. In making comparisons about size, I wonder if there is an International Association of Cemeteries as there is, say, an International Association of Airports, and if so, do they keep tally by territorial size, or by the number of bodies that have been sowed under, as airports count size by the number of passengers? Both are spaces of fluidity.

An estimated 1,500,000 people have been buried in Vila Formosa since it opened in 1949. In a city of eleven million people, that is a lot, given the tens of public and private cemeteries that also exist. If death was a big business in Brazil as it is in the United States, things would be dramatically different. In Brazil, though, state payments for health-related services go less systematically and fluidly to third parties - old age homes, caregivers, hospitals, and so forth - that keep poor people alive, indebting them and turning them into commodities, until their death and an eventual pay out. In Brazil, everyone gets a free, if sparse, burial. The city of São Paulo pays and manages most of the cemeteries. They are public, open to all, and made open for all. They are highly organized, even if pieces of coffin, bone, and plastic commemoration lie everywhere. They must be, due to the number of people they handle. Their management is utterly modest, having succumbed to the demands of routine burial and disinterment.

Just outside one of Vila Formosa's gates is a single flower seller. In this social space, people find ways to commemorate given the deep constraints. Just getting to the cemetery can be a challenge since it is in the city's eastern reaches, far from metro and arterial bus lines. To get here is easiest for those who live in this part of the city, where "quality of life" is significantly lower than in wealthy neighborhoods. People in the latter bury their dead in places like Cemitério da Consolação, where tourists go to see the ornate tombs, sculptures, and permanent funerary rites. That cemetery's walls are topped with razor wire to keep out tomb raiders. Outside its walls, on a busy thoroughfare across from the Medical School and Hospital of the University of São Paulo, is a row of around fifty flower vendor stalls. While they now sell also to passing motorists, these vendors are historically rooted in the creation and display of bouquets to commemorate death, and they compete for a lively market.

The contrast with Vila Formosa is extreme. At Vila Formosa they commemorate with small granite plaques, spinning wheels, plastic flowers, and figurines. Disinterred gravesites reveal something about these commemorations. Fragments of pine or similar woods remain in some, while in others bits of medium-density fiberboard have blended into the earth around, leaving behind only bits of shiny faux-wood laminate (see figure 2).

On one of my visits there, a cold wind blew through the trees. The night before dropped to 4 degrees Celsius, very cold for São Paulo. On the way to the 


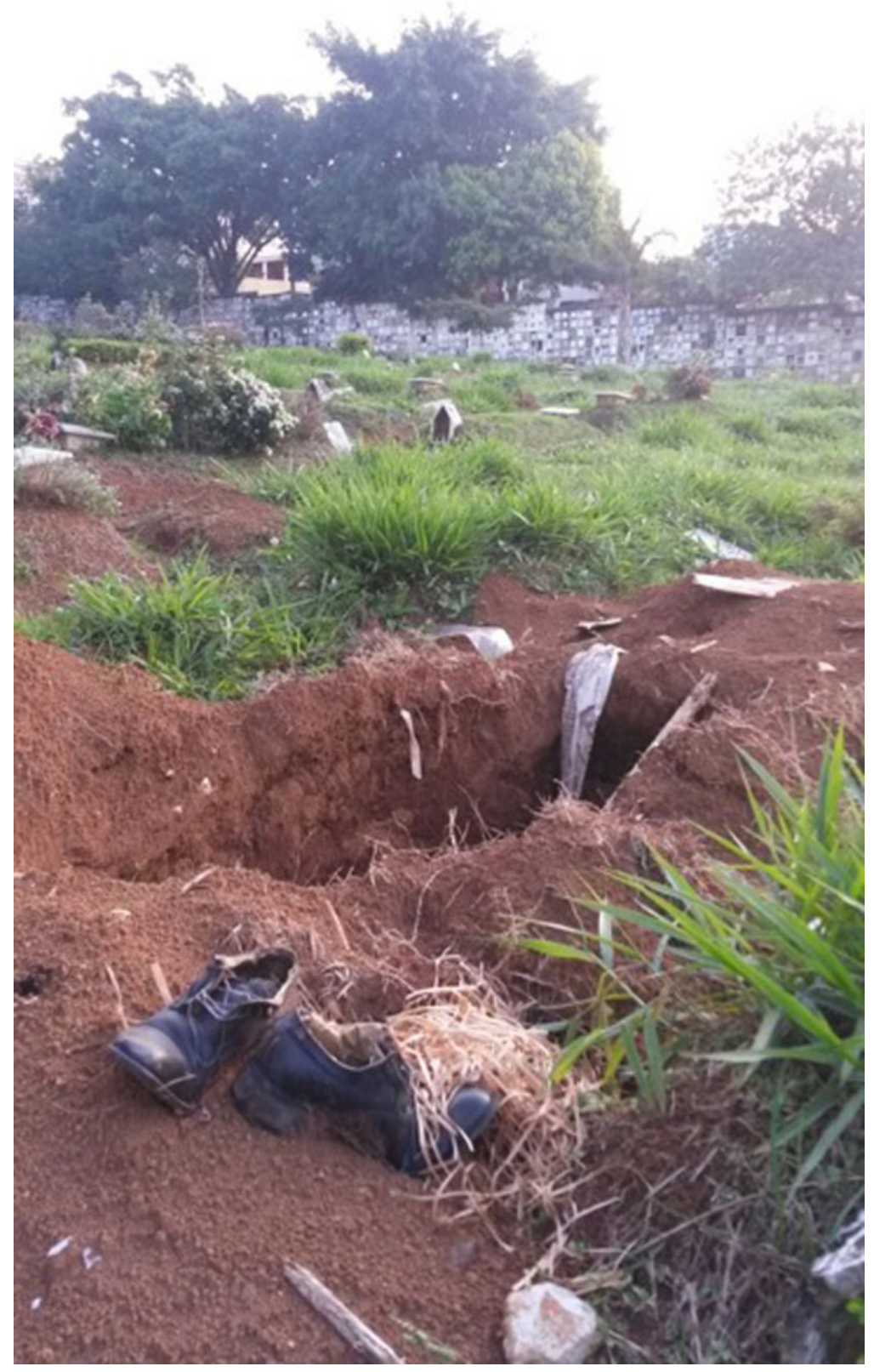

FIGURE 2. Fragments. 
cemetery the taxi driver told me that a six-year-old boy who had been living with his parents on the street had died of hypothermia. We conjectured that he, like us, might be going to Vila Formosa. The asphalt road leading up from one of the cemetery's three entrances is broken to pieces, and the exposed earth beneath is patterned in rivulets from hard rains. At the entrance gate a small, unattended fire of plastic and garbage burns, flickering against a wall and turning it black with ash. Stray dogs run about, bouncing around the mounds and holes in the ground. On my first visit, sensing that I was unfamiliar, they barked and stayed close to the grave workers, who barely noticed me. Our car had pushed up the hill, beneath a row of towering trees. Bureaucrats had planned this as a tree-lined boulevard. One can see the idea, but while some trees are still alive others are burned out, hollow shells.

Most of the dead from the Carandiru massacre are buried here, eightyseven of them (Rezende n.d). This momentous massacre early in Brazil's re-liberalization period is often seen as evidence of the shift in categories of state violence away from the killing of real or suspected political insurgents and toward those - criminals, the poor - who might usurp economic prosperity. Most of the eighty-seven have long since been disinterred and moved to the ossuary. Basic burial includes three years in the ground. After that, if no one foots the bill for them to remain buried, bodies are pulled up, one by one, shovelful by shovelful, handful of bone by handful of bone, placed in a plastic bag alongside thousands of others in a mass grave.

Vila Formosa is the place where many of the urban poor are buried today, through an incessant routine. Every fifteen minutes a body is put in the ground. Sometimes families arrive, mull about for a few minutes, and then leave. Rows of pre-dug graves await. Those whose relatives have paid the fee stay in the ground, but the terrain around them is dotted with disinterred graves of those buried three years before. Disinterment takes place daily from 9:00 a.m. to 12:00 p.m., carried out by a special shovel-bearing crew. But there is no time to collect everything in the coffins. What comes up in exhumations are the big bones and what is left of larger remnants such as clothing, shoes, or plastic items. These go into overflowing dumpsters. Most of the coffin stays in the ground, as does much of the body. Forget about any small bones like fingers, hands, or feet, or even some bigger ones; there is no time (see figure 3 ). The next burial will go on top. This is a disinterment not of reclamation or reconciliation, but of disposal.

The history of Vila Formosa is significant, particularly starting with Brazil's Cold War government. The beginning of Brazil's dictatorship in 1964 brought a wave of state violence. In 1968, the state's counterinsurgency actions accelerated with the signing of an "Institutional Act" (AI-5) that abolished habeas corpus, established media censorship, and closed the National Congress and state assemblies. This act effectively centralized power in the federal government under the pretense of national security, and resulted in a 


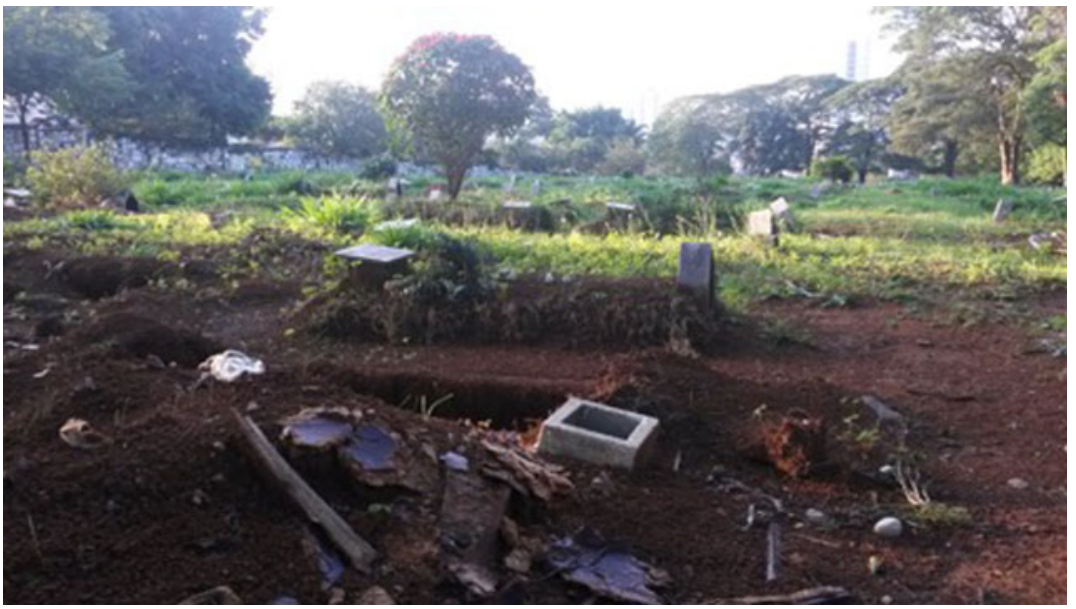

Figure 3. There is no time.

highly coordinated campaign against real and perceived political dissidents, which in turn led to an explosion of killings and disappearances.

In São Paulo, many of those killed by police and "communist hunting" extermination groups ended up in the ground at Vila Formosa, where they were buried as nameless indigents or under false names. Only rarely were they released to family members. An extensive report by the organization

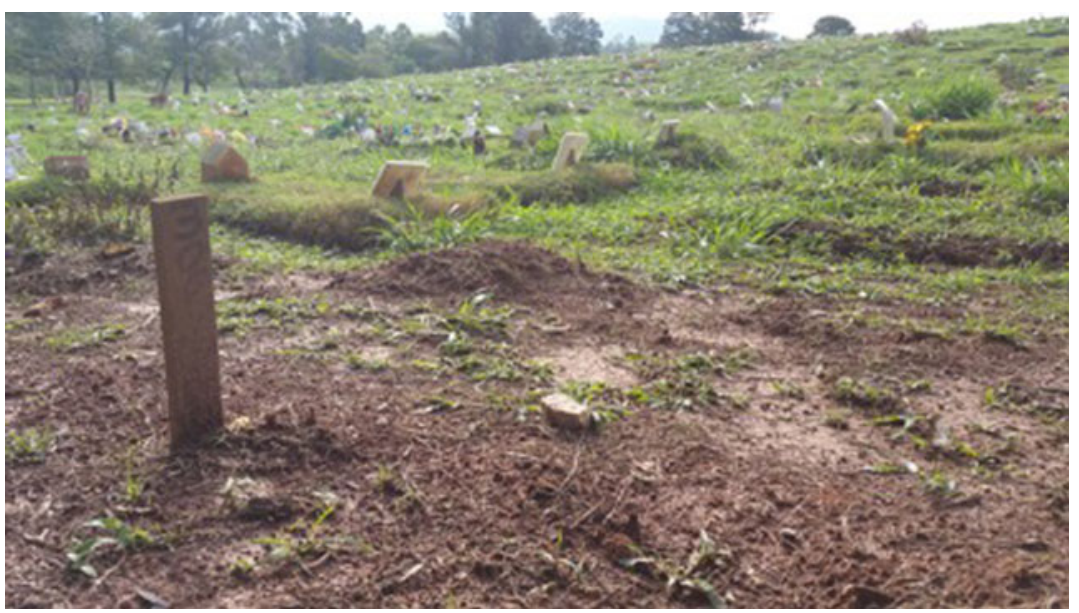

Figure 4. Dom Bosco. 
Grupo Tortura Nunca Mais ("torture never more") (1995), details the fate of fourteen such insurgents at Vila Formosa, and draws direct lines from their political activity to state repression and subsequent efforts to make them disappear into Vila Formosa's potter's field. One such case is as follows:

Hamilton Fernando Cunha, Militant of the Popular Revolutionary Vanguard (VPR). Born in Florianopolis in 1941, son of Fernando Manoel Cunha and Filomena M. Rosa. Killed by machine gun on February $11^{\text {th }} 1969$ while resisting arrest, as police from the Department of Social and Political Order attempted to capture him at his workplace. The police version of the repressive event states that Hamilton had been shot by a revolutionary companheiro, who escaped unidentified, when police announced he was under arrest. He was buried as an indigent at Vila Formosa Cemetery in São Paulo (ibid.: n.p.).

Also among these known burials was the country's most prominent leftist revolutionary, Carlos Marighella. He was a leader of the National Liberation Action, a group known for having kidnapped the United States Ambassador in 1969. His actions as a Marxist became internationally famous from his book Minimanual of the Urban Guerilla (1969). Marighella is perhaps the most publicly known person ever buried at Vila Formosa, defying the place's insignificance. Writes Bonassi,

...a striking tomb where the ants are having a party calls my attention. It is particularly striking next to its surrounding neighbors. I approach the mound of earth where these ants party. A wooden cross falling over has one of its arms buried. I try to read, gella, quella, ghella ... the letters are of a time that remind me of music, of particular words. I smile. A dust devil forms. A hand pulls me violently back. It is my dad. He keeps pulling me back while looking to the horizons and the concrete ossuaries that surround the place. He orders me never to return. He says it is the tomb of a terrorist, and that the police could be watching. It took me some time to understand why the police would be watching a dead person. To me, from that day forward, "terrorista" comes from "terra," the soft earth and ant hills of the largest cemetery in Latin America (1996, quoted in Rezende n.d).

In 1969, though, the police were themselves looking to make bodies disappear, unwatched. The terrorist must be made silent in death, un-commemorated. With the killing of political insurgents then on the upswing under the new federal powers, political leaders sought to make their own repressive violence entirely invisible. Vila Formosa was too busy. This potter's field was of declining usefulness for their purposes.

On 2 March 1971, the state consecrated Dom Bosco cemetery on the far northern reaches of the city. Surrounded by steep hillsides and green forests, and only reasonably accessible by car, this remote cemetery was purportedly the city's first burial ground for indigents, the unclaimed, and the abandoned. But much more was underfoot. The government contracted a British firm called Dowson and Mason to build an industrial grade cremation furnace there. This company was surprised to learn that a cremation furnace was 
necessary, given the design of the cemetery and the purpose of such a furnace, and they wrote a note to raise their concerns:

It seems this project has no funeral hall, and has some things, frankly, that we cannot understand-even though we have been incorporated and working for fifteen years on cremation projects around the world.... We would like to know the reasons why two enormous entrances to the cremation room, where the actual cremations take place, are necessary given that this is usually a discrete place where few people ask to be. It would be especially disturbing for these doorways to remain open all the time for the general public or anyone to see inside (quoted in Bobadilla n.d).

They did not realize that Dom Bosco was not meant to be a public place. It was designed to be a closed factory that would allow a high flow of bodies to disappear in no-nonsense ways. At the height of a political moment in which the Brazilian government was being increasingly and internationally implicated in tortures and disappearances, the inhumane design frightened the contractors, and in the end Dowson and Mason did not build the furnace. In some ways this did not matter, and Dom Bosco remained a cemetery for indigents, and under this guise it became a site for the disposal of political insurrection. It drew little attention in a period when public congregations and organized political activities of any kind were prohibited.

Twenty years later, in September of 1990, and with the support of São Paulo's first female mayor, human rights workers and forensic anthropologists excavated a 30-meter-long trench at the site that opened up a mass grave with 1,049 bags of bones and another 525 bodies. Dom Bosco became the focal point of a national discussion of, and contested reconciliation with, the violence of the dictatorship period. International forensic and human rights experts visited and wrote reports, and the case made headlines globally. Years later, investigations continue, but at a snail's pace. Political involvement with the process, including meddling in the universities responsible for the remains, has stalled advances. The search to identify political dissidents was revitalized in 2014 and has gained new momentum; 151 of the 1,049 boxes have been opened and 144 sets of bones have been analyzed. Of the bones catalogued, eighty-one are from males and twenty-four from females (Nuzzi 2015).

The discussion about democracy and reconciliation that surrounds Dom Bosco is the main reason the cemetery enters public discourse. And yet there are striking paradoxes: of those buried at Dom Bosco, it is believed that only twenty were suspected Cold War political dissidents. The rest-many more than a thousand-are nameless individuals of the potter's field. These are not simply the infirm, the destitute, or those without families. They include also victims of the extermination squads that patrolled the poor and informally urbanizing spaces of São Paulo during the same period. The murders of these voiceless individuals have proved easy to obscure in the category and soil of the indigente. It is remarkable how little we know, even now, about these "paupers" who commingle with the reclaimable dead. 
Those who continue to be interred or obscured as indigents at Vila Formosa and Dom Bosco receive little attention beneath the heavy history of state terror associated with the place. Walking on the modest grounds of Dom Bosco, where gravesites consist largely of wooden stakes, 10' x 10' granite plaques, unmarked grassy mounds, and jumbled headstones, a commemorative wall looms as a reminder of that terror. Painted in solid red with white letters, it reads: "Here the dictators tried to hide the politically disappeared, victims of hunger, of the violence of a police state, of the death squads, and above all of the rights of poor citizens of the city of São Paulo. Be it registered that these crimes against freedom will always be discovered." Subscribing the text is the name of Luiza Erundina de Sousa São Paulo's mayor during the early 1990s and a political progressive and federal senator today. While a testament to egregious violence past, it recognizes the many other victims of political injustice. And yet it stands, solemnly, at the background of a politically forgotten field where countless young men are buried every day, many of them between ages fifteen and thirty. On investigation, one headstone plaque tells a story of a police operation that resulted in the arrest of four men and the killing of the twenty-year-old named Wesley buried under my feet. His grave plaque reads, "With the love of his parents and siblings."

Though Wesley was claimed by his family, a staggering number of "unclaimed" people remain. The need to mitigate costs is severe, and new solutions are always being sought. Every Saturday since April 2014 the city of São Paulo updates a municipal webpage that provides tens of new names of indigents sent to the potter's fields of Dom Bosco and Vila Formosa. Over the three years since the webpage first appeared, 2,152 have been listed (Prefeitura n.d). Many suffered deaths from treatable "let die" health complications, such as pneumonia or septic shock, that occurred in places like "a public thoroughfare" (ibid.). Many other listings cite violence and trauma as the cause of death.

Take one example of a police killing: Police shot and killed Marcelo Sabino dos Santos following a vehicle chase down a major highway. Unclaimed at the morgue, he was sent to Dom Bosco. A newspaper report recounted what happened:

A police chase on Wednesday afternoon ended with a shootout, one dead and one wounded on Pinheiros Ring Road near the Eusebio Matos bridge. The incident caused the lanes toward Interlagos to be totally obstructed between 1 p.m. and 2 p.m., creating 7 kilometers of backup. Around 2:15 p.m. the lanes at the incident and the express lanes were opened up.

It all began when two armed thugs accosted businessman Mauricio Menezes, fortysix, at a gas station at Ponte Bandeiras, on Tiete Ring Road at around 12:50 p.m. The thieves forced him to get out of his car and drove off. "All I could hear was them shouting: 'You lose! You lose!' Then I got out of the car." Menezes managed to stop a Military Police car, which began the chase. 
Near the Remédios Bridge, the thugs collided with a number of cars and hit a motorcyclist. Rescue was called and the victim taken to hospital.

Further along on Pinheiros Ring Road the robbers ran the car into an abutment and skidded across the lanes. Immediately after, the shootout with police began. One of the robbers was killed and the other injured. The police helicopter assisted in the work. "When the shootout began I could only think of saving my car and the death of the two thugs," affirmed Menezes.

After five hours of traffic paralysis the Pinheiros Ring Road was clear for motorists. The body is with analysts. It will then be sent to the coroner [Instituto Médico Legal (IML)]. No identity information is yet available for the dead man (Veja 2014).

The article's emphasis on how this incident interrupted urban life for a specific few, and its characterization of the individuals as "thugs"-bandidos-who deserved to die, are striking. That the first sentence about a police killing immediately shifts to a second sentence about traffic consequences speaks volumes about what is implied. The robbed man's open desire to see them dead, while striking in this story, is a common trope among large segments of society, and it also defines many aspects of policing.

Subsequent media reports identified the dead "thug" as Marcelo. The entry on the municipal potter's field webpage makes a transparent connection to the incident: "Marcelo Sabino dos Santos, 26, born 21/09/1987, died 21/05/ 2014, son of Antonio José dos Santos and Maria das Dores Sabino dos Santos, Police Report 392/14, 51 ${ }^{\circ}$ Precinct, place of incident Pinheiros Ring Road, 6800 , Interlagos, multiple bullet wounds, sent by Central Coroner for free burial at Dom Bosco Cemetary in Perus" (Prefeitura n.d.). I was unable to find Marcelo's grave at Dom Bosco, and other aspects of his case are equally elusive: whether his parents could not afford to collect him, whether he was estranged, or whether he was simply alone and poor and thus turned to crime. But these questions are extraneous to his social identity as a killable individual. It is likely that Marcelo's remains now lie under a single wooden stake marked by a number written in felt pen. By the time the present article appears, he will already have been disinterred, placed in a plastic bag, and stored alongside thousands of others.

\section{THE POTTER'S FIELD, UNCERTIFIED}

Foucault argued that "the reverse of biopolitics is thanatopolitics" (2000: 416). As the state cares for its citizens through biopolitics, so is it "entitled to slaughter" through a politics of death (ibid.). Thanatopolitics, as the politics of death, practiced through political abandonment and terror, creates an abundance of bodies. The current politics of death transcends state certified cemeteries, settling and motivating possibility beyond state delineation. Those who would be slaughtered so absolutely by police and abandonment are not vapid or listless. They speak and act, both through and in response to violence. Murray (2006) asks the important question: what would it mean to speak in the name of death? He gives the example of suicide bombers. 
Another example is that of "organized crime" and its cemeteries. The uncertified potter's field is a terrestrial manifestation of what a politics of abandonment makes possible. In a late liberal moment, scholars have rightly revisited questions of sovereignty and the fracturing, transcendence, or symbiosis of political order relative to states (Nordstrom 2000; Hansen and Stepputat 2006). Where there are spatial practices of emergent sovereignty, it follows that there should be questions about where those slaughtered find their earthly place. It does not follow that the bodies that contemporary slaughter produces will always end up in a certified cemetery.

Starting in 2009, almost immediately after Rio de Janeiro was awarded the 2016 Olympics, the city's police initiated a new public security policy intended to remove "drug gangs" from informally urbanized but strategically located hillside favelas. Called "pacification," this policy, slowly applied, relentlessly and combatively sought to retake control of spaces governed by these highly racialized and prison-rooted "gangs." This exceptional Olympic effort exposed something unexceptional for those living in these communities: the discovery of burial fields in these recently "pacified" spaces soon became mundane news. Police found them at the tops of hillsides in at least seven different favelas during the early years of the policy, and many surely never made the news. In these fields, armed groups buried those they killed for transgressing rules about crime in the community, acts deemed wrong such as sexual violence and "snitching."

Organized crime and its violence and sovereign characteristics are not new, but why has the potter's field now moved beyond state bureaucracy? Conditions of abandonment, and the specter and sharp edge of violence and undignified burial are enablers. Where such conditions become extreme, it becomes easy for them to transcend certified spaces. A clear example of this in São Paulo is the evolution of the PCC organized crime group. The PCC is a byproduct of the Carandiru prison massacre, where survivors were stripped naked and made to pile the dead in rows as blood flowed "shin deep" across their legs (Magalhães and Novaes 2013). According to the words of the PCC's own statute, written one year later and now widely available, "The Primeiro Comando da Capital PCC, founded in 1993, in a monstrous and tireless fight against oppression and the injustice at the concentration camp 'attached' to the Taubate House of Custody and Treatment, has as an absolute theme 'Liberty, Justice, and Peace.",

Others have convincingly argued that this group emerged as both a resistance to terror and a form of governance outside of the state (Alves 2016; Biondi 2010). Today, the PCC is a regime of both care and slaughter: a collective of self-defined criminals rooted in urban spatial practices of informality, which has codified rules that follow the fluid movement of young black men between the urban periphery and the prisons. They are, their once-leader said, filhos da miséria; "sons of misery." The PCC enforces a social order 
beyond its "baptized" members, and asserts a governing function in communities in many historically violent parts of the city and throughout the prison system of São Paulo state. ${ }^{2}$ The organization is credited with presiding over a "peace among criminals" - paz entre ladrões. It enforces rules about how violence is to be used - where, why, and upon whom - through a complex system of formalized tribunals that bring together victims, suspects, family members, "legal" defense and prosecution, and local community members (Biondi 2010; Feltran 2011; Dias 2013). Internal documents of the group, given to me by a gatekeeper in the public security system, tell us a great deal. ${ }^{3}$ The PCC maintains a graduated system of punishment that has been codified with surprising bureaucratic rigor. Standardized reporting of punishments happens via templated documentation that includes twelve different fields of data ranging from the number of members punished to the names of "godfathers." This system of bureaucratic management, aimed largely at decreasing violence, is coordinated by leaders who are in prison. Members have learned and constructed this alternative system of justice by drawing on their direct experiences with the violent injustices of the state's justice system. This alternative system imposes severe punishments on those who break cardinal rules about sexual abuse, theft from the organization, and killing or harming anyone without prior authorization.

Questions of violent death are central to the organization, and not just in the practice of violence. They are deeply concerned that their own people die with dignity rather than suffering death from unjust police executions or capture and torture by police or rivals, or burial in a pit with no commemoration. This concern represents a redefinition of care. There are clear examples. When one member was killed by police while carrying out PCC business, members accounted for his death and outstanding drug debts in a bureaucratic document. In doing so, they also noted the importance of providing money for his proper burial:

Known as: Marcos

Neighborhood: Quarrytown

Amount of loss: 650.00 in weed and 3,993 in coke from 12/2010

OBS: Marcos was done in during an operation in which he was hit and injured and he was in the hospital for a few days but died. The brothers from the city passed along that for a funeral to take place they need help because the family does not have the conditions to do a burial.

This appeal resulted in a separate document dated from the next month that accounts for the organization's drugs sales, costs, and expenditures. In it I

${ }^{2}$ This is increasingly the case in many other states in Brazil as well. Recent massacres in prisons in the far north were a result of fighting between the PCC and rival groups.

${ }^{3}$ In 2012 a worker in São Paulo's public security system gave me a trove of electronic documents consisting of PCC punishment and drug sales records, seized in a series of arrests. I have analyzed these extensively elsewhere (Denyer Willis 2017; Lessing and Denyer Willis n.d.). 
find a line between " 360.00 for cost of car to take family members back home from visit to W2 prison" and "700.00 for Fred's trip to the capital city," which reads: "1,900 re: payment of funeral for our oldest brother from Quarrytown."

Marcos was not Wesley or Marcelo, but he could have been, and under slightly different conditions the PCC might not have paid for his burial. The PCC regularly pays the funeral expenses for those it cares for. In this case, the $\mathrm{R} \$ 1,900$ Brazilian Reais they paid is roughly three times the monthly minimum wage, and $\mathrm{R} \$ 1,600$ more than the $\mathrm{R} \$ 300$ required to avoid ritual disinterment after three years. This notion of care means ensuring an appropriate mortuary ritual and a proper coffin in a certified cemetery. It also means that the body will not be disposed of in the pit.

The PCC's high degree of organization in this regard may be unusual. With thousands of members over a diffuse territory, it must write things down for future consultation. But a basic pattern is evident: incipient forms of order that redraw which lives must be cared for also must redraw which lives need not be. The latter can and must be slaughtered. In Rio de Janeiro and elsewhere, this generates a noticeable pattern of materiality and burial space.

The consequences of this pattern of social order were obvious during the time I spent with São Paulo's homicide detectives, disclosed in burial pits that dot the city's landscape. There are many media reports of such clandestine cemeteries, including on YouTube and other social media platforms (G1 2010; R. Ribeiro 2016; R7 2013). These boneyards are sometimes large and well organized. They are used repeatedly, with burials occurring in different periods as necessary. One found in 2016 held thirty bodies. A hallmark of these PCC fields is that the bodies are buried head down and show evidence of violent deaths.

One particular field, located in the city's far south side, is striking for its material parallels and systemic position. Police were led there on a tip from a local community member who told them to "Have a look at the ground next to the cemetery, beside a fence" (A. Ribeiro 2016). After searching through a densely wooded area they found an area of recently disturbed earth. Digging, they discovered a foot, and hours later, with many more people digging, three bodies. Eventually they found at least three others, with every indication that still more remained.

What makes this field noteworthy is not its existence per se, but that it existed, and was used repeatedly, immediately adjacent to a certified cemetery. That cemetery has the same name as the informally urbanized community that surrounds it, "Cherry Tree Park" (Parque das Cerejeiras). Yet this is a private cemetery, consecrated and made legal by the state but not run by it. The owners declare on their website that it is made in the "American Model" (Memorial Parque das Cerejeiras 2016), with expansive green space, grounds secured by twenty-four-hour private security, surveillance cameras, and gates 
manned via a fortified outpost. Its grounds are adorned with twenty-two landscape sculptures by a named artist, a pond with Asian carp, "ecological trails," and a viewing platform that looks out over a green vista that resembles a neatly manicured golf course. This is not a typical Latin American cemetery of mausoleums or dirt mounds bored through by ants. This is a new place, mirroring the most privileged kind of life in liberal death.

POTTER'S FIELDS: BONES BEGET BONES

What is the relationship between Cherry Tree Park and this potter's field? The earth between them is indistinguishable. And yet they are separated by a wall that inscribes in earth a material distinction between the legal- the certifiedand the illegal. But is that difference what matters? In fact, this wall is irrelevant, at least in terms of political will. Cherry Tree Park and the uncertified cemetery are the same in the sense that a liberal democratic moment, by legal institution and by omission, allows both to exist as byproducts of state practices that normalize the PCC and similar groups. Following Roy, we might argue that uncertified potter's fields can serve as a "...device that uncovers the ever shifting urban relationship between the legal and the illegal, legitimate and illegitimate, authorized and authorized" (2011: 233). These two spaces are mutually constituted and intertwined, bound together in everyday practice and assumption, and accepted as ordinary.

And yet, what is peripheral is central to the logic of power. I have argued elsewhere that the black urban poor are used to justify security, wealth, and status for those who tell themselves they deserve it (2015). This ability to make such categories matter is a sovereign prerogative. As Diken argues, "All contemporary urban space is organized according to the logic of the favela" (2005: 307). The favela, the black body, the uncertified cemeteryall are routinely referenced as forms of barbarity, vindicating the walls, policing, and inequality. And yet this space transcends the law and also the walls that circumscribe it.

In March 2017, Mexican police unearthed a burial pit outside of Vera Cruz in which they found the jumbled remains of at least 250 people. This case is important and exceptional in three ways. First, this enormous cemetery was discovered by family members searching, in defiance of the state's apathy, for missing loved ones believed to be buried in pits scattered across the Mexican countryside. Movements for this purpose, which are now commonplace across Mexico, practice a kind of citizenship to liberalism that is enabled, not surprisingly, by "bake sales and raffles" (Villegas 2017).

Second, some of Mexico's uncertified cemeteries are exceptional in their scale. In the years since the exceptional violence of 2007-2011, with tens of thousands missing, it is their size that grabs public attention. To find one with twenty corpses is not worthy of note, but discovery of one with more than two hundred is. 
Third, such a space encapsulates the obscured logics of the liberal violence of abandonment. Though the state's institutions do not need to kill, they routinely do so. Political power must displace responsibility for its violence onto individuals or the violent groups that are made possible, perhaps necessary, under such a logic of political order. The uncertified cemetery, while not a direct outcome of the state, becomes useful to it as a material invocation of responsibility interred elsewhere. When these burial fields are made noteworthy -250 corpses! - a suite of rote questions flood in: How many were innocent? Who among them should be reclaimed? How much will this all cost to sort out? All of these questions confound the problem and deploy the same logic of value. Such notions of innocence and productive life enable the practice of uncertified cemeteries.

These questions become more pressing in the everyday life of a megacity. How does it matter that we are not asking questions about mundane mass graves of people "left to die," or about the ways in which the uncertified cemetery is written with its own novel paradigm of innocence and productivity? The potter's field reflects the varying spatial organizations and value logics of historical moments, located far from the conquistador's churchyard, whether they be in a mass grave for the destitute of Poor Law England, the indentured prisoners of Hart Island, or those killed by police in São Paulo. Such conditions are political, and they are useful to those with political power.

But if the specter of the potter's field has catalyzed forms of organization historically, how does it serve the same purpose today, as we fill these fields in uninterrupted flows? And how does it matter that those who worry about burial conditions are not "simply" newsboys or street kids? Though they are easily obfuscated as "illiberal" gangs, organized crime, and paramilitary groups are systemic forms of sociality. They are, in this way, a kind of insurance against disposal in a mass grave, a Victorian "burial society" in other times by other means.

To put this differently, the potter's field can tell us a great deal about what many of us take for granted: that in moments of "humanitarian reason" mass graves are conventional. This is why the potter's field is so deeply unnerving. It reveals, materially, how privilege is implicated in violence while it also compels us to recognize ways that apparently illiberal varieties of politics are in fact legitimate forms of sociality.

\section{REFERENCES}

Ahnen, Ron. 2003. Between Tyranny of the Majority and Liberty: The Persistence of Human Rights Violations under Democracy in Brazil. Bulletin of Latin American Research 22, 3: 319-39.

Alves, Jaime. 2014. Neither Humans nor Rights: Some Notes on the Double Negation of Black Life in Brazil. Journal of Black Studies 45, 2: 143-62. 
Alves, Jaime. 2016. "Blood in Reasoning": State Violence, Contested Territories and Black Criminal Agency in Urban Brazil. Journal of Latin American Studies 48, 1: 61-87.

Aretxaga, Begoña. 2003. Maddening States. Annual Review of Anthropology 32: 393-410.

Arias, Enrique and Daniel Goldstein. 2010. Violent Democracies in Latin America. Durham: Duke University Press.

Baudrillard, Jean. 1993. Symbolic Exchange and Death. London: SAGE.

Bernstein, Nina. 2016. Unearthing the Secrets of New York's Mass Graves. New York Times, 15 May. At: http://www.nytimes.com/interactive/2016/05/15/nyregion/newyork-mass-graves-hart-island.html (last accessed 30 July 2017).

Biehl, João. 2005. Vita: Life in a Zone of Social Abandonment. Berkeley: University of California Press.

Biondi, Karina. 2010. Junto e Misturado-Uma Etnografia do PCC. São Paulo: Terceiro Nome.

Blakely, Robert and Judith Harrington, eds. 1997. Bones in the Basement: Post-Mortem Racism in Nineteenth-Century Medical Education. Washington, D.C.: Smithsonian Institution Press.

Bobadilla, Kassia. n.d. A Ditadura Militar em São Paulo: O Caso da Ossadas dos Desaparecidos de Perus. At: http://www.fespsp.org.br/seminario2013/artigos/IISeminario Pesquisa_KassiaBobadilla.pdf (last accessed 30 July 2017).

Bonassi, Fernando. 1996. 100 Hístorias Colhidas na Rua. São Paulo: Scritta.

Bourgois, Phillippe. 2001. The Power of Violence in War and Peace: Post-Cold War Lessons from El Salvador. Ethnography 2, 1: 5-34.

Caldeira, Teresa. 2000. City of Walls: Crime, Segregation and Citizenship in São Paulo. Berkeley: University of California Press.

Castex, Graciela. 2007. Social Workers' Final Act of Service: Respectful Burial Arrangements for Indigent, Unclaimed, and Unidentified People. Social Work 52, 4: 331-39.

Cingranelli, David and David Richards. 1999. Respect for Human Rights after the End of the Cold War. Journal of Peace Research 36, 5: 511-34.

Comaroff, Jean and John Comaroff, eds. 2006. Law and Disorder in the Post-Colony. Chicago: University of Chicago Press.

Darke, Sacha. 2013. Inmate Governance in Brazilian Prisons. Howard Journal of Crime and Justice 52, 3: 272-84.

De León, Jason. 2015. The Land of Open Graves: Living and Dying on the Migrant Trail. Oakland: University of California Press.

Denyer Willis, Graham. 2014. Antagonistic Authorities and the Civil Police in São Paulo, Brazil. Latin American Research Review 49, 1: 3-22.

Denyer Willis, Graham. 2015. The Killing Consensus: Police, Organised Crime and the Regulation of Life and Death in Urban Brazil. Oakland: University of California Press.

Denyer Willis, Graham. 2016. City of Clones: Facsimiles and Governance in São Paulo, Brazil. Current Sociology, Online First 0011392116657295.

Denyer Willis, Graham. 2017. Before the Body Count: Homicide Statistics and Everyday Security in Latin America. Journal of Latin American Studies 49: 29-54.

de Walque, Damien. 2005. Selective Mortality during the Khmer Rouge Period in Cambodia. Population and Development Review 31, 2: 351-68.

Dias, Camila. 2013. PCC-Hegemonia Nas Prisões e Monopólio da Violência. São Paulo: Saraiva.

DiGirolamo, Vincent. 2002. Newsboy Funerals: Tales of Sorrow and Solidarity in Urban America. Journal of Social History 36, 1: 5-30. 
Diken, Bülent. 2005. City of God. City 9, 3: 307-20.

Drybread, Kristen. 2013. Social Life and the Deaths of Brazilian Street Children. Journal of Latin American and Caribbean Anthropology 18, 2: 212-30.

Engels, Friedrich. 1892. The Condition of the Working Class in England. London: Swan Sonnenschein \& Co.

Feltran, Gabriel. 2011. Fronteiras de Tensão: Política e Violência nas Periferias de São Paulo. São Paulo: UNESP.

Ferrándiz, Francisco and Antonius Robben. 2015. Necropolitics: Mass Graves and Exhumations in the Age of Human Rights. Philadelphia: University of Pennsylvania Press.

Fontes, Anthony. n.d. Making the Maras: Death and Doubt in Guatemala City. Oakland: University of California Press (forthcoming).

Foucault, Michel. 2000. The Political Technology of Individuals. In James Faubion, ed., Power: Essential Works of Foucault, 1954-1984. Vol. 3. New York: New Press, 403-17.

Fox, Mim. 2005. To Die Destitute Today: What Are the Implications for Social Work? Australian Social Work 58, 2: 188-98.

G1. 2010. Polícia Encontra Cemitério Clandestino na Zona Leste de SP. Globo. At: http://g1.globo.com/sao-paulo/noticia/2010/07/policia-encontra-cemiterio-clandestinona-zona-leste-de-sp.html (last accessed 29 July 2017).

Gill, Lesley. 2004. The School of the Americas: Military Training and Political Violence in the Americas. Durham: Duke University Press.

Goldstein, Daniel. 2016. Owners of the Sidewalk: Security and Survival in the Informal City. Durham: Duke University Press.

Gordillo, Gaston. 2002. The Breath of the Devils: Memories and Places of an Experience of Terror. American Ethnologist 29, 1: 33-57.

Grupo Tortura Nunca Mais. 1995. Dossiê Dos Mortos e Desaparecidos Políticos a Partir de 1964. Recife: Companhia Editora de Pernambuco. At: https://www. marxists.org/portugues/tematica/livros/diversos/mortos.pdf (last accessed 29 July 2017).

Hansen, Thomas Blom and Finn Stepputat. 2006. Sovereignty Revisited. Annual Review of Anthropology 35: 295-315.

Heryanto, Ariel. 2006. State Terrorism and Political Identity in Indonesia: Fatally Belonging. London: Routledge.

Holston, James. 2009. Dangerous Spaces of Citizenship: Gang Talk, Rights Talk and Rule of Law in Brazil. Planning Theory 8, 1: 12-31.

Hurren, Elisabeth. 2004. A Pauper Dead-House: The Expansion of the Cambridge Anatomical Teaching School under the Late-Victorian Poor Law, 1870-1914. Medical History 48, 1: 69-94.

Jones, Gareth, Elsa Herrera, and Sarah Thomas de Benítez. 2007. Tears, Trauma and Suicide: Everyday Violence among Street Youth in Puebla, Mexico. Bulletin of Latin American Research 26, 4: 462-79.

Kaufman, Sharon and Lynn Morgan. 2005. The Anthropology of the Beginnings and Ends of Life. Annual Review of Anthropology 34: 317-41.

Kim, Jieun. 2016. Necrosociality: Isolated Death and Unclaimed Cremains in Japan. Journal of the Royal Anthropological Institute 22, 4: 843-63.

King, Roy and Bruna Valensia. 2014. Power, Control, and Symbiosis in Brazilian Prisons. South Atlantic Quarterly 113, 3: 503-28.

Klaufus, Christien. 2016. Deathscape Politics in Colombian Metropolises: Conservation, Grave Recycling and the Position of the Bereaved. Urban Studies 53, 12: 2453-68. 
Koonings, Kees and Dirk Kruijt. 1999. Societies of Fear: The Legacy of Civil War, Violence and Terror in Latin America. London: Zed Books.

Laqueur, Thomas. 1983. Bodies, Death, and Pauper Funerals. Representations 1: 109-31.

Laqueur, Thomas. 2015. The Work of the Dead: A Cultural History of Mortal Remains. Princeton: Princeton University Press.

Lessing, Ben and Graham Denyer Willis. n.d. Legitimacy in Criminal Governance: Regulating a Drug Empire from Behind Bars. MSS (under review).

Lomnitz, Claudio. 2005. Death and the Idea of Mexico. New York: Zone Books.

Magalhães, Vagner and Marina Novaes. 2013. "Fiquei com Sangue até o Meio da Canela," Diz Perito do Carandiru. Terra Online. At: https://noticias.terra.com.br/ brasil/policia/fiquei-com-sangue-ate-o-meio-da-canela-diz-perito-do-carandiru,e0dc5 afed16dd310VgnVCM4000009bcceb0aRCRD.html (last accessed 29 July 2017).

Marighella, Carlos. 1969. Minimanual of the Urban Guerilla. At: https://www.marxists. org/archive/marighella-carlos/1969/06/minimanual-urban-guerrilla/ (last accessed 29 July 2017).

McSherry, J. Patrice. 2012. Predatory States: Operation Condor and Covert War in Latin America. New York: Rowman \& Littlefield.

Memorial Parque das Cerejeiras. 2016. Webpage. At: http://www.cerejeiras.com.br (last accessed 29 July 2017).

Mitchell, Michael and Charles Wood. 1999. Ironies of Citizenship: Skin Color, Police Brutality, and the Challenge to Democracy in Brazil. Social Forces 77, 3: 1001-20.

Murray, Stuart. 2006. Thanatopolitics: On the Use of Death for Mobilizing Political Life. Polygraph: An International Journal of Politics and Culture 18: 191-215.

Nagengast, Carole. 1994. Violence, Terror, and the Crisis of the State. Annual Review of Anthropology 23: 109-36.

Nordstrom, Carolyn. 2000. Shadows and Sovereigns. Theory, Culture \& Society 17, 4: $35-54$.

Nuzzi, Vitor. 2015. Última Etapa para as Ossadas de Perus: Perto, Talvez, da Identificação. Rede Brasil Atual. At: http://www.redebrasilatual.com.br/cidadania/2015/02/ ossadas-de-perus-9472.html (last accessed 29 July 2017).

O’Neill, Kevin Lewis. 2012. There Is no More Room: Cemeteries, Personhood, and Bare Death. Ethnography 13, 4: 510-30.

Prefeitura. n.d. Falecidos IML/SVOC. At: http://www.prefeitura.sp.gov.br/cidade/ secretarias/obras/servico_funerario/falecidos/index.php? $\mathrm{p}=229658$ (last accessed 1 Aug. 2017).

R7. 2013. Cemitério clandestino é encontrado na zona leste de SP. R7. At: http://noticias. r7.com/sao-paulo/cemiterio-clandestino-e-encontrado-na-zona-leste-de-sp-24062013 (last accessed 29 July 2017).

Rawlings, Philip. 1995. The Idea of Policing: A History. Policing and Society: An International Journal 5, 2: 129-49.

Rezende, Eduardo. n.d. O Enigma dos Cemitérios da Cidade de São Paulo. At: http:// www.cemiteriosp.com.br/pdf/Enigma_cem_\%20cidade_SP.pdf (last accessed 29 July 2017).

Ribeiro, Aline. 2016. Um Sobrevivente do Tribunal do Crime. Época. At: http://epoca. globo.com/tempo/noticia/2016/07/sob-o-dominio-do-crime-um-sobrevivente-dotribunal-do-pcc.html (last accessed 29 July 2017).

Ribeiro, Rafael. 2016. Tribunal do Crime Enterra 30 Pessoas de Cabeça Para Baixo em São Paulo. Folha de São Paulo. At: http://m.folha.uol.com.br/cotidiano/2016/02/ 1743551-tribunal-do-crime-enterra-30-pessoas-de-cabeca-para-baixo-em-sao-paulo. shtml (last accessed 29 July 2017). 
Riley, John Jr. 1983. Dying and the Meanings of Death: Sociological Inquiries. Annual Review of Sociology 9, 1: 191-216.

Rochlin, James. 2003. Vanguard Revolutionaries in Latin America: Peru, Colombia, Mexico. Boulder: Lynne Rienner Publishers.

Rosenblatt, Adam. 2015. Digging for the Disappeared: Forensic Science after Atrocity. Palo Alto: Stanford University Press.

Roy, Ananya. 2011. Slumdog Cities: Rethinking Subaltern Urbanism. International Journal of Urban and Regional Research 35, 2: 223-38.

Rubin, Jonah. 2015. Technologies of the Afterlife: The Agency of the Dead at Spanish Mass Grave Exhumations. Anthropological Journal of European Cultures 24, 1: 141-49.

Samet, Robert. 2013. The Photographer's Body: Populism, Polarization, and the Uses of Victimhood in Venezuela. American Ethnologist 40, 3: 525-39.

Sanford, Victoria. 2003. Buried Secrets: Truth and Human Rights in Guatemala. New York: Palgrave.

Sappol, Michael. 2002. A Traffic of Dead Bodies: Anatomy and Embodied Social Identity in Nineteenth-Century America. Princeton: Princeton University Press.

Scheper-Hughes, Nancy. 1993. Death without Weeping: The Violence of Everyday Life in Brazil. Berkeley: University of California Press.

Silvestre, G. 2016. Local Consequences of the Prison Policies in State of São Paulo, Brazil: A Case Study of the Town of Itirapina. Crime, Law and Social Change 65, 3: 269-85.

Simone, Abdul Maliq. 2016. City of Potentialities: An Introduction. Theory, Culture \& Society 33, 7-8: 5-29.

Sluka, Jeffrey. 2000. Death Squad: The Anthropology of State Terror. Philadelphia: University of Pennsylvania Press.

Stepputat, Finn, ed. 2014. Governing the Dead: Sovereignty and the Politics of Dead Bodies. Manchester: Manchester University Press.

Strange, Julie-Marie. 2003. Only a Pauper Whom Nobody Owns: Reassessing the Pauper Grave c. 1880-1914. Past \& Present 178: 148-75.

Taussig, Michael. 1984. Culture of Terror-Space of Death. Roger Casement's Putumayo Report and the Explanation of Torture. Comparative Studies in Society and History 26, 3: 467-97.

Veja. 2014. Troca de Tiros na Marginal Pinheiros Termina Com um Morto. Veja São Paulo. At: http://vejasp.abril.com.br/materia/perseguicao-policial-interdita-marginalpinheiros (last accessed 29 July 2017).

Verdery, Katherine. 2013. The Political Lives of Dead Bodies: Reburial and Postsocialist Change. New York: Columbia University Press.

Villegas, Paulina. 2017. More Than 250 Human Skulls Are Found in Mass Grave in Mexico. New York Times, 14 Mar. At: https://www.nytimes.com/2017/03/14/world/ americas/mexico-veracruz-mass-grave.html (last accessed 29 July 2017).

Wacquant, Loïc. 2003. Toward a Dictatorship over the Poor? Notes on the Penalization of Poverty in Brazil. Punishment \& Society 5, 2: 197-205.

Weld, Kirsten. 2014. Paper Cadavers: The Archives of Dictatorship in Guatemala. Durham: Duke University Press.

Wilson, Richard. 2001. The Politics of Truth and Reconciliation in South Africa: Legitimizing the Post-Apartheid State. Cambridge: Cambridge University Press. 
Abstract: I unpack the "potter's field" as an everyday practice and a category, especially as it operates in the material treatment of bodies as a mirror of life. I examine this space of "worthlessness" as it exists in liberal capitalism. From the potter's fields of São Paulo, Brazil, I consider how these are, in fact, mundane mass graves, made politically useful as a means to obscure important bodies alongside those who are, today, the subjects of terror. I then ask how the rise of the uncertified potter's field - a burial field for disposable bodies, not made legal by the state - is inseparable from recent historical and contemporary conditions of political abandonment. The uncertified field is made easy by a politics of abandonment, and becomes useful to state institutions as a material invocation of responsibility, interred elsewhere, while nonetheless advancing a larger logic of governance and political will in our times.

Key words: mass graves, indigent cemetery, potter's field, São Paul, Brazil, violence, abandonment, liberalism 